\title{
Regulation on Genetically Modified Animals: Proposed and Its Possible Application in Indonesia
}

\section{(Regulasi Tentang Ternak Termodifikasi Genetik: Usulan dan Kemungkinan Penerapannya di Indonesia)}

\author{
Bess Tiesnamurti ${ }^{1}, \mathrm{~S}$ Muharsini ${ }^{2}$ and MI Shiddieqy ${ }^{1}$ \\ ${ }^{1}$ Indonesian Center for Animal Research and Development, Jalan Pajajaran Kav E59, Bogor 16128, Indonesia \\ ${ }^{2}$ Indonesian Research Center for Veterinary Sciences, Jalan RE Martadinata No. 30 PO BOX 151, Bogor 16114, Indonesia \\ Kontributor utama: besstiesnamurti@yahoo.com
}

(Diterima 20 Oktober 2021 - Direvisi 22 November 2021 - Disetujui 14 Desember 2021)

\begin{abstract}
The government is responsible for fulfil the needs of safe, healthy and halal food for all its people in a sustainable manner. The world population will increase from 7 to 9 billion people in 2050. While the availability of land may not increase in the future, it may even not be used for agriculture. Scientists are trying to overcome this problem by creating technologies that can increase livestock productivity, one of which is through a genetically modified process. Genetically modified animals are animals that have been genetically modified for many purposes including yields and disease resistance. Although genetically modified animals are at the last stage of research and the possibility to entering Indonesia remains small, but government should prepare a regulation related to it. European countries and USA have regulations to control genetically modified animals. Malaysia also has applied a similar regulation since 2007. Currently, Indonesia has formed an authority that oversees the genetically modified product, namely Biosafety Commission (Komisi Keamanan Hayati) on genetically modified products. However, this commission only supervises genetically modified organism in food and feed. This paper is aimed to propose the regulation for genetically modified animal that may be entering Indonesia and or be researched by Indonesian scientists.
\end{abstract}

Key words: Regulation, genetically modified organism, animal

\begin{abstract}
ABSTRAK
Pemerintah mempunyai tanggung jawab untuk memenuhi kebutuhan pangan aman sehat dan halal bagi seluruh penduduknya. Pada tahun 2050 diperkirakan populasi manusia akan bertambah dari 7 milar menjadi 9 milyar orang, dipihak lain, ketersediaan lahan boleh jadi tidak akan bertambah. Seandainya pun tersedia, akan banyak terjadi alih fungsi lahan sehingga peruntukan bagi kegiatan pertanian kemungkinan berkurang. Para peneliti mencoba mengatasi hal ini melalui penciptaan teknologi yang akan meningkatkan produktivitas ternak, diantaranya melalui proses modifikasi genetik (GM). Ternak yang termodifikasi gen nya dapat dipergunakan untuk berbagai kepentingan, misalnya peningkatan produksi dan meningkatkan ketahanan terhadap penyakit. Walaupun saat ini, penelitian ternak GM ada yang sudah masuk dalam fase akhir riset dan belum akan memasuki wilayah Indonesia, akan tetapi pemerintah harus mempersiapkan regulasi terkait. Negara Uni Eropa dan Amerika Serikat telah mempunyai regulasi tentang GM ternak, hal serupa telah dimiliki negara Malaysia sejak tahun 2007. Saat ini, pemerintah Indonesia telah mempunyai Komisi Keamanan Hayati Produk Rekayasa Genetik. Tetapi komisi ini hanya menangani produk GM pangan dan pakan. Makalah ini menyampaikan usulan regulasi untuk GM ternak yang kemungkinan akan memasuki wilayah Indonesia maupun GM ternak hasil penelitian dalam negeri.
\end{abstract}

Kata kunci: Peraturan, modifikasi genetik, ternak

\section{INTRODUCTION}

World population will rise from 7 to 9 billion people in 2050 (OECD 2012). According to United Nations Millennium Goals, the targets include reduce by half the share of the global population suffering from hunger. However, the goal is not easy to be reached. Food insecurity is both an immediate tragedy and threat to longer-term well-being. Families tend to reduce higher-quality food intake, such as meat or vegetables (Dewbre 2010). Land, water and biological resources are declining at an alarming rate, this loss has significant negative impacts on the production of food and forests (Crist et al. 2017).

Agriculture sector plays an important role in lowincome countries because they have high economic dependency on that sector (Brools 2012). In Indonesia, agricultural sector remains important factor, comprising $13.45 \%$ of the country's aggregate Gross Domestic Product (GDP) or the second largest after 
industrial sector (19.62\%) in Quarter 3 (Q3) 2019 (BPS 2019). The Indonesian government organized many programs for the realization of food security, although many obstacles in their implementation (Andoko et al. 2018). Increasing food production is important for all countries including Indonesia, but several countries are not self-sufficient and depend on imports from other regions (D'Odorico et al. 2014).

Animal agriculture also needs to increase its production. In the future, demand for animal food products will increase, mostly in developing countries. The global livestock sector is rapidly changing in response to globalization and growing demand for animal-source foods, driven by population growth and increasing wealth in much of the developing world. The rapid rate of urbanization seen in many countries is not only linked to growing affluence but also gives rise to changes in people's food preferences, usually tending towards greater convenience and higher standards of safety (Robinson et al. 2011).

Growing two or more crops in the same land increased yields, especially in Asian countries (Taiz 2013). Genetic engineering reached an important progress during the 1980s which triggered the development of genetic modification (GM). At the most basic level, a genetically modified organism (GMO) is any organism whose genetic material has been altered using genetic engineering techniques (Veitenheimer 2016).

First GMO crop launched in 1994 as the "FlavrSavr" tomato (Taiz 2013). While the discussion on the risks, the general necessity and the economically optimal levels of synthetic pesticide use has not come to an end, today GM raise concerns in many parts of civil society (Zadoks \& Waibel 2000). In a traditional breeding program, a breeder selects desirable parental plant lines to cross, but the changes occurring at the genetic level are unpredictable (Veitenheimer 2016). There are also numerous benefits of GMO. The prospect of GM crops offering increased yield potential for important food crops on a per acre basis is one way to address the world's increased demand for food. Some GM crops also decrease synthetic chemical pesticide utilization and lower the environmental impact associated with such use.

Underlining those advance, fast biotechnology and the need to provide foods for the human population, this paper is aimed to propose the regulation for animal GMO that may be entering Indonesia and be researched by Indonesian scientists.

\section{THE GLOBAL STATUS OF GM ANIMAL}

Regulations on GM crops and GM animals have been issued by countries in various parts of the continent (Pasquito 2019; Viera et al. 2021; Kuiken \&
Kuzma 2021). Indonesia can take lessons from the country's experience and adapt to the existing conditions.

The most frequently genetically engineered crop species are the big three of cotton, corn, and soybeans (Veitenheimer 2016). However, engineered animal species are also developing. Animal's genetic modification includes altering its genetic material by adding, changing or removing certain DNA sequences which do not occur naturally (EFSA 2012). The aims of the genetic modification are to modify specific characteristics or introduce a new trait, such as resistant to disease or increased growth. Initially, GM animals were used for laboratory purpose. Genetically defined laboratory mice have been described and incorporated into biological research; this trend has accelerated in the $21^{\text {st }}$ century (Pritchett-Corning \& Landel 2015). However, effort has been made to modify several aspects of farm animals to improve their cultivation (Cotter \& Perls 2019; Lievens et al. 2015). Amongst the most targeted traits are: animal health (increased neonatal survival), disease resistance, growth rate, improvement of meat and milk composition. Three categories can thus be defined: GM animals for human consumption, as medical bioreactors, and as companion animal. The first GM animal that enter the food chain is salmon. United States Food and Drug Administration (FDA) has approved a new animal drug application concerning AquAdvantage Salmon, a genetically engineered Atlantic salmon. There are at least 74 (ongoing) attempts at animal modification, of which about half are designed for use as livestock. Amongst the latter, at the majority are intended for direct release onto the food market (as meat or meat product) as opposed to animals for wool or milk production.

The number of GM animals for which we were able to find (partial) sequence information was approximately around 56 items. Of all the genetically modified animals listed, there is currently only AquAdvantage salmon that is actually being brought into production (Lievens et al. 2015). According to EFSA (2013), no GM animals or derived products are on the EU market, nor have any applications for GM animals been received in the EU.

Table 1 showed recent molecular research of transgenic animals with potential applications. Indonesia with 265 million population has high consumption of animal products, especially in the future. The beef cattle population in Indonesia is $17,118,650$ head while the population of dairy cattle is 561,061 head (Indonesian Ministry of Agriculture, 2020). Demand of beef and milk are 686,270 tons and 1.098.125 tons, respectively, while the production of beef and milk are 490,400 tons and 996,400 tons, respectively. Beef import is around $40 \%$ of the total demand which is equivalent to $204,682.78$ tons of live 
cattle and processed beef products as much as $164,260.57$ tons

Milk supply is also came from abroad as much as $79 \%$ (equivalent to $455,559.47$ tons) of milk and dairy products. Countries of origin are Netherlands, Australia, New Zealand, and United States. Seeing the opportunity for beef and milk demand is very high, it is necessary to anticipate with regulations if GM livestock, meat products, eggs and GM milk will enter Indonesia, especially by looking at the risks posed both in terms of the environment. There is possibility that the exporting country in the future will send GM beef or milk.

Indonesian researchers (Faculty of Fishery and Maritime at University of Pajajaran, Bandung, West Java) already carried out the insertion of growth genes in catfish, and already produced GM fish. Therefore, it is necessary to have regulatory on animal genetically modified organism. Meanwhile, research related to gene modification in other livestock, has not been recorded or carried out in Indonesia.

Table 1. Overview some of the transgenic animals with potential commercial applications

\begin{tabular}{|c|c|c|c|c|}
\hline Species & Category & Transgene & Origin & Effect/goal \\
\hline \multirow[t]{5}{*}{ Cattle } & Livestock & Lysozyme & Human & Milk composition \\
\hline & & a,k-Case & Bovine & Milk composition \\
\hline & & Omega-3 & Nematode & Milk composition \\
\hline & & Lysostaphin & Bacterial & Mastasis resistance \\
\hline & Bioreactor & Lactoferrin & Human & Prophylactic treatment \\
\hline \multirow[t]{4}{*}{ Chicken } & Livestock & alv6 envelope glycoprotein & Viral & Disease resistance \\
\hline & & short hairpin RNA & Viral & Disease resistance \\
\hline & & LacZ & Bacterial & Animal Health \\
\hline & Bioreactor & a-interferon & Human & Hepatitis treatment \\
\hline \multirow[t]{2}{*}{ Carp } & Livestock & Growth Hormone & Piscine & Growth rate \\
\hline & & Lactorferrin & Human & Disease resistanc \\
\hline Catfish & Livestock & Cercopin B & Insect & Disease resistanc \\
\hline Fruit Fly & Livestock & fsRIDL & Hymnopteran & Pest control \\
\hline Frog & Bioreactor & GFP & Cnidarian & Water purity \\
\hline \multirow[t]{9}{*}{ Goat } & Livestock & Lysozyme & Human-Bovine & Animal Health \\
\hline & & Monosat. fat. acid & Rat-Bovine & Mastasis resistance \\
\hline & & $\operatorname{MSP}(1) 42$ & Plasmodial & Malaria vaccine \\
\hline & & Antithrombin III & Human & Thrombosis/embolism treatment \\
\hline & & Tissue plasminogen activator & Human-Mouse & Anti clotting agent \\
\hline & & Lactoferrin & Human & Prophylactic treatment \\
\hline & & Lysosomalacid b-glucosidase & Human & Gaucher disease treatment \\
\hline & & Human coagulation factor IX & Human & Haemophilia treatment \\
\hline & & Human beta-defensin 3 & Human & Milk composition \\
\hline \multirow[t]{10}{*}{ Pig } & Livestock & Phytase & E. coli Mouse & Feed uptake \\
\hline & & Growth hormone & Human-Porcine & Growth rate \\
\hline & & cSKI & Chicken & Muscle development \\
\hline & & Lysozyme & Human & Piglet survival \\
\hline & & Unsat. fat. acid & Spinach & Meat composition \\
\hline & & Omega-3 & Nematode & Meat composition \\
\hline & & a-lactalbumin & Bovine & Piglet survival \\
\hline & & Mx1 & Murine & influenza resistance \\
\hline & Bioreactor & Factor VIII & Human & Haemophilia treatment \\
\hline & & CD59, DAF & Human & Human transplantation \\
\hline
\end{tabular}




\begin{tabular}{|c|c|c|c|c|}
\hline Species & Category & Transgene & Origin & Effect/goal \\
\hline \multirow{15}{*}{ Rabbit } & \multirow{15}{*}{ Bioreactor } & DAF & Human & Human transplantation \\
\hline & & hHO-1 & Human & Human transplantation \\
\hline & & hHO-1,DAF & Human & Human transplantation \\
\hline & & b-D Mamose, GnTIII & Human & Human transplantation \\
\hline & & Fibrinogen & Human & Tissue sealant \\
\hline & & Haemoglobin & Human & Transfusion \\
\hline & & Protein C & Human & Blood coagulation \\
\hline & & Albumin & Human & Human transplantation \\
\hline & & Calcitonin & Salmon & Osteoporosis treatment \\
\hline & & Erythropoietin & Human & Anemia treatment \\
\hline & & Superoxide dismutase & Human & Blood purification \\
\hline & & Interleukin-2 & Human & Cancer treatment \\
\hline & & Tissue plasmogen activator & Human & Anti Clotting Agent \\
\hline & & VP2, VP6 & Viral & Rotavirus vaccine \\
\hline & & Human Factor VII & $\begin{array}{l}\text { Human-Mouse- } \\
\text { Chicken }\end{array}$ & Haemophilia treatment \\
\hline \multirow{5}{*}{ Salmon } & \multirow{5}{*}{ Livestock } & Growth Hormone & Human & HGH insufficiency treatment \\
\hline & & Von Willebrand factor & Human-Bovine & Haemophilia treatment \\
\hline & & Growth hormone & Piscine & Growth rate \\
\hline & & Growth hormone & Piscine & Growth rate \\
\hline & & Lysozyme & Piscine & Animal health \\
\hline \multirow{3}{*}{ Sheep } & \multirow{3}{*}{ Livestock } & wflAFP-6 & Piscine & Cold tolerance \\
\hline & & IGF-1 & Ovine & Wool growth \\
\hline & & CsK & Bacterial & Wool growth \\
\hline \multirow{10}{*}{ Silkworm } & \multirow{5}{*}{ Bioreactor } & HTT & Human & Disease model \\
\hline & & Visna resistance & Viral & Disease resistance \\
\hline & & Factor IX & Human & Haemophilia treatment \\
\hline & & Factor VIII & Human & Haemophilia treatment \\
\hline & & a-1-antitrypsin & Human & Cystic fibrosis treatment \\
\hline & Livestock & eGFP, DsRed, or & Cnidarian & Silk color \\
\hline & \multirow{4}{*}{ Bioreactor } & $\mathrm{A} 2 \mathrm{~S} 8_{14}$ & Arachnid & Silk strength \\
\hline & & Fibroin & Human & Cell adhesive film \\
\hline & & Crp & Canine & Inflammation marker \\
\hline & & TRACP5B & Human & Inflammation marker \\
\hline Tilapia & Bioreactor & Insulin & Human & Diabetes treatment \\
\hline Trout & Livestock & Follistatin & Piscine & Muscle development \\
\hline Zebrafish & Companion & GFP or RFP & Cnidarian & Fish color \\
\hline
\end{tabular}

Sumber: Lievens et al. (2015)

Several types of animal that have been carried out research on genetic modified organism are cattle, goats, sheep, chickens, pigs, rabbits, carp, catfish, tilapia, fruitfly, frog, salmon, trout, zebrafish and silkworm. While the genes under studied are intended to solve problems in human health, such as for the treatment of mastasis, malaria vaccines, anti-clotting agents, haemophilia treatment, human transplantation, transfusion, anemia problems and many others (Lievens et al. 2015). For example, to help the problem of anemia in humans, the genes are taken from humans and then use rabbits as bioreactors to produce Erythropoietin. This Erythropoietin then can be utilized to help curing the anemia treatment. Cooperation can 
be done between agencies or companies that have GM animal patents to enter Indonesia for futher development, as well as GM crops, which are widely imported into Indonesia recently and have been subjected to risk assessments by the Biosafety Technical Team. Certain livestock growth is not optimal because it is not resistant to parasitic attacks, while overseas research has been conducted and produced research for animals that are resistant to certain diseases. In addition, there is a tendency for children under five who are not resistant to lactic acid in cow's milk, so that in the future cow milk will be produced which is tolerant of lactic acid for infants.

\section{NATIONAL BIOSAFETY REGULATION}

\section{The avalaible legislation}

The Cartagena Protocol was a strong commitment among parties that regulates across borders of living organism that derived from genetically modified organism from modern biotechnology process either from private and or institute overseas or nationally produced. The protocol ensure reliable protection in term of transit, handling and safety utilization from cross border movement of GMO products. The protection level was conducted to avoid negative effect toward sustainable and utilization of genetic resources as well as its risks for human being. Indonesia ratified the Cartagena Protocol on August 16, 2004 by implementing Law No 21/2005 regarding the authentication of Cartagena Protocol on Biosafety to the Convention on Biologiocal Diversity. Until February 2019 at least 172 countries from 180 parties already entry into force of the Cartagena Protocol. Some of these countries have the regulations on genetically modified animals (Table 2)

Indonesian Biosafety Clearing House already established as stated in article No 20 of Cartagena Protocol to facilitate information exchange interm of scientific, technical, environment and regulation about GMO. Base on article No. 77 paragraph (1), Act No. $18 / 2012$ about foods and state that "every human being are not allowed to produce foods derived from GMO that has not been approved on biosafety before distributed", then followed by amandmend of that regulation to No. 6/2018 of food control genetically modified organism. Based on Government Regulation No. 21/2005, Commision on Biosafety was the institution that assigned for risk assessment. To facilitate operational activities for risk assessment, the Biosafety Technical Team for Food, Feed and Environment was established. Food biosafety certificate was granted by the Director General of National Agency of Drug and Food Control, feed biosafety certificate was granted by Ministry of Agriculture and environment biosafety certificate was granted by Ministry of Environment and Forestry. Regulation related to biosafety regulation in Indonesia is shown in Table 3.

Table 2. Regulations on genetically modified animals in selected countries and regions

\begin{tabular}{|c|c|}
\hline Countries/Regions & Regulation \\
\hline \multirow[t]{2}{*}{ European Union } & $\begin{array}{l}\text { Regulation (EC) No } 1829 / 2003 \text { of the European Parliament and of the Council of } 22 \text { September } 2003 \text { on } \\
\text { genetically modified food and feed }\end{array}$ \\
\hline & $\begin{array}{l}\text { Directive 2001/18/EC of the European Parliament and of the Council of } 12 \text { March } 2001 \text { on the deliberate } \\
\text { release into the environment of genetically modified organisms and repealing Council Directive } \\
\text { 90/220/EEC }\end{array}$ \\
\hline Norway & $\begin{array}{l}\text { Gene Technology Act of } 2 \text { April } 1993 \text { No. } 38 \text { relating to the production and use of genetically modified } \\
\text { organisms, etc }\end{array}$ \\
\hline United States & $\begin{array}{l}\text { Guidance for Industry on Regulation of Genetically Engineered Animals Containing Heritable } \\
\text { recombinant DNA Constructs; Availability (Docket No. FDA-2008-D-0394) }\end{array}$ \\
\hline Argentina & Law on the Promotion of the Development and Production of Modern Biotechnology, Law 26270, 2007 \\
\hline Australia & Gene Technology Act 2000, implemented by Gene Technology Regulations 2001 \\
\hline New Zealand & Hazardous Substances and New Organisms Act 1996 \\
\hline Brazil & $\begin{array}{l}\text { Law No. } 11.105 \text { of } 24 \text { March 2005. Safety standards and inspection mechanisms for activities involving } \\
\text { Genetically modified organisms - GMOs - and their derivatives, creates the National Biosecurity } \\
\text { Council (CNBS), restructures the National Biosecurity Technical Commission (CTNBio), and rearranges } \\
\text { the National Biosecurity Policy (PNB) }\end{array}$ \\
\hline South Africa & Genetically Modified Organisms Act, 1997 (No. 15 of 1997) \\
\hline Nigeria & National Biosafety Management Agency Act, 2015 \\
\hline Malaysia & Biosafety Act 2007 \\
\hline
\end{tabular}


Table 3. Biosafety Regulation in Indonesia.

\begin{tabular}{|c|c|}
\hline Regulation & Topic \\
\hline Law No. 5 /1994 & United Nation Convention on Biological Diversity (CBD) \\
\hline Decree of Four Minister / 1999 & Biosafety and Agriculture Genetic Modified Organism of Food Biosafety \\
\hline Law No. 21/2004 & Ratification of Cartagena Protocol \\
\hline Government Regulation No.21/2005 & Biosafety of Genetic Modified Organism \\
\hline $\begin{array}{l}\text { Ministry of Agriculture Decree No } 37 / \\
2006\end{array}$ & Testing, Reviewing and Releasing of Crop Variety \\
\hline $\begin{array}{l}\text { Ministry of Agriculture Decree No } 67 \text { / } \\
2006\end{array}$ & Conservation and Utilization of Plant Genetic Resources. \\
\hline Law No. 32/2009 & Environment Protection and Management \\
\hline Ministry of Agriculture Decree No 36/2016 & Biosafety Risk Assessment for Feed \\
\hline $\begin{array}{l}\text { Regulation of National Agency of Drug and } \\
\text { Food Control No. } 6 / 2018\end{array}$ & Supervision on Genetically Modified Food Product \\
\hline Ministry of Agriculture Decree No 38/ 2019 & Testing, Reviewing and Release of Crop Variety \\
\hline $\begin{array}{l}\text { Ministry of Agriculture Decree No 50/ } \\
2020\end{array}$ & $\begin{array}{l}\text { Supervision and Controlling Plant Varieties of Agricultural Genetically } \\
\text { Modified Organisms Distributing in the Territory of the Republic of Indonesia }\end{array}$ \\
\hline
\end{tabular}

Table 4. GM animals and associated differences in environmental effects (EFSA, 2013)

\begin{tabular}{|c|c|c|c|}
\hline Description & Confined GM animals & Semi-confined GM animals & Non Confined GM animals \\
\hline Definition & $\begin{array}{l}\text { GM animals intended to be } \\
\text { kept under confinement }\end{array}$ & $\begin{array}{l}\text { GM animals intended to be under } \\
\text { human control but not always under } \\
\text { confinement }\end{array}$ & $\begin{array}{l}\text { GM animals } \\
\text { released into } \\
\text { environments }\end{array}$ \\
\hline $\begin{array}{l}\text { Examples for GM } \\
\text { mammals or birds }\end{array}$ & $\begin{array}{l}\text { Chicken (except free-range); } \\
\text { pigs; fenced mammals; caged } \\
\text { birds; companion animals } \\
\text { held indoors }\end{array}$ & $\begin{array}{l}\text { Cats; cattle or goats sometimes } \\
\text { browsing on an unfenced pasture }\end{array}$ & $\begin{array}{l}\text { Rabbits released to control } \\
\text { wild populations }\end{array}$ \\
\hline \multirow[t]{2}{*}{$\begin{array}{l}\text { Environmental } \\
\text { effects }\end{array}$} & $\begin{array}{l}\text { Environmental effects of } \\
\text { confined GM animals }\end{array}$ & $\begin{array}{l}\text { Environmental effects during } \\
\text { confinement periods }\end{array}$ & $\begin{array}{l}\text { Environmental effects of } \\
\text { released GM animals }\end{array}$ \\
\hline & $\begin{array}{l}\text { Environmental effects of } \\
\text { escaped GM animals }\end{array}$ & $\begin{array}{l}\text { Environmental effects during non- } \\
\text { confinement periods } \\
\text { Environmental effects of escaped GM } \\
\text { animals }\end{array}$ & \\
\hline
\end{tabular}

During the last 15 years after the ratification and entry into force of Cartagena protocol, the government of Indonesia already produced 41 biosafety certificates such as events of maize, soybean, canola, potato and feed additive, ice cream stabilizer and vaccines. Some events of GM maize, were imported for human consumption and feed, whereas other events will be planted for production (such as corn, sugarcane, potato and soybean). After granted the biosafety certificates of environment, food and feed, the designated varieties have to follow procedure for releasement. The Decree of Ministry of Agriculture No. 50/2020 was an expectation for GM plant varieties to be cultivated, however, those varieties require biosafety certificates of food, environment and feed.

\section{Proposed regulation for GM animal}

In a protocol published by EFSA (2013), it stated that GM animal are species of fish, bird and livestock. EFSA (2013) reported three confined facilities for GM animals, such as Confined GM animals, Semi-confined GM animals and Non Confined GM animals as shown in Table 4. If Indonesia would like to prepare and facilitate risk assessment for GM animals, therefore one needs to consider component such as GM animals for breeding stock, GM animals for food and also GM animals as bioreactor that require to be regulated.

GM animal, livestock, insect and fish are not regulated at the previous regulation schemes. To anticipate that GM livestock will enter Indonesia, there 
is a need to prepare the regulation. These GM livestock could be as breed stocks or and readily consumed products or even pharmaceutical products derived from GM livestock and or animal. Nowdays, the available regulation only for environment risk assessment plants according to the Decree of Ministry of Environment and Forestry No. P.69/Menlhk/Setjen/Kum.1/8/2016 regarding testing procedure of environment biosafety of GMO at Limited Field Test. The upcoming law on Genetic Resources is expected to cover the utilization of genetic resources in Indonesia. On the other hand, regulation for GMO breed stocks has not been available yet, underlining those circumstances, procedures of GM livestock can be proposed as follows:

Breeding stock. Risk assessment needs to be conducted for genetic materials from genetic modified (GM) processes, both for incoming materials or GM animals produced in Indonesia. Frozen semen, frozen embryo, oocytes, premordial germ cell, fertilized eggs and live animals are genetic materials resulted from breeding of GM animals. The risk assessment for breeding stock that will be carried out consists of reviewing the documents submitted by the proponent, then followed by observations of the GM animals as part of the field tests. EFSA classified GM animals risk assessment according to their intended uses, within the three groups such as confined, semi-confined and nonconfined GM animals (Table 4).

At the very beginning, frozen semen from GM bulls, GM embryos or GM live animals can be imported, the risk assessment conducted through reviewing the documents from the proponent. However, after the frozen embryos transfered to the recipient animals, or by conducting AI (artificial insemination) of the frozen semen, then the recipient and the offsprings required substantial risk assessment based on GM confined animals. At this point, environment technical assessment team which include member of animal aspect needed to be established. This is due to the fact that most Indonesia's environment for livestock rearing are under confinement. Therefore protocols for the environment effects and the possibilities of the environmental effects that may come from escaped GM animals must be reviewed in details.

The risk analysis elements of the breeding stocks (Table 5) include of hazard characterisation, exposure characterization (high, moderate, low or negligible). The component of risk assessment can be divided into 1) Molecular characterisation, 2) Compositional characterisation, 3) Phenotypic characterisation and 4) Interaction between the GM animal and its receiving environment. The molecular information include of 1) genetic information (consist of genetic element, source of the gene, transformation system, genetic stability),
2) biosafety information (substantial equivalent, toxicity (bioinformatics study, toxicity test) (EFSA 2013).

The phenotypic parameters required for risk assessment of breeding stocks include of 1) production data (body weight, growth rate, carcass percentage, egg production, milk production, milk quality, meat quality, egg quality etc according to the species being assessed) , 2) reproduction data (sperm quality, mature age, age at first mating, body weight at first mating, puberal age etc), 3) disposal from the animals (urine, manure), 4) other products (feather, leather), 5) processing of the urine and manure, 6) disease that may occur during the assessment, 7) mortality rate and 8) physiological data of the animals (rectal temperature, heart rate as well as respiration rate) (EFSA 2013).

GM Animals Products. In the future, GM Animal products possibly come into the market, eventhough the research has not been conducted in Indonesia. Products from GM animals can be as meat, milk, eggs, wool, leather, honey and bones that require risk assessed by food biosafety technical team. The GM animals products can be in a wide range such as their products and also the result from their processing. The output from processing such as from milk processing (yoghurt, cheese, kefir etc), product of egg processing (powdered eggs, albumin powder, egg yolk powder, egg yolk liquid etc) and products of meat processing (sausage, smoked beef, meatball, nuggets etc).

The risk assessment for GM Animals Products (Table 5) include of 1) Molecular characterisation and 2) Compositional characterisation. Data required for risk analysis molecular characterisation include of 1) general description of GM animal product (description of the host and its use as food; description of gene sources; description of genetic transformation methods and characterization of genetic modification); 2) food safety information which includes substantial equivalence; changes in food composition; allergenicity; toxicity; and 3) other considerations include of marking genes for antibiotic resistance; potential accumulation of substances that have a significant impact on human health The compositional characterisation include of proximate analysis, amino acid content, mineral content, secondary compund etc.

The goals of livestock GM research generally fall into three categories such as increased yield, increased the cost-effectiveness in keeping animals (e.g., certain disease resistance) and changes in the quality of nutrition for milk, meat or eggs (Cotter \& Perls, 2019). Examples of genetically engineered animals in development include of super-muscle of cows, sheep and pigs. Due to many diseases problems in chicken and pigs, therefore considerable GM researches are conducted for resistant to the respiratory disease for pig and chicken. An ongoing experiment is conducted 
Table 5. Proposed biosafety risk assessment of GM breedstock and product of GM livestock .

\begin{tabular}{lccc}
\hline \hline Type of product & Document assessment & Biosafety containment test & Contained field test \\
\hline Breeding Stocks & & & \\
Semen (frozen and fresh) & Yes & Yes & Yes \\
Embryo(frozen and fresh) & Yes & Yes & Yes \\
Fertilized eggs & Yes & Yes & Yes \\
Live animal & Yes & Yes & Yes \\
GM Livestock Products & & & No \\
Meat & Yes & No & No \\
Milk & Yes & No & No \\
Egg & Yes & No & No \\
Livestock Bioreactor Products & & & No \\
Enzyme & Yes & No & No \\
Hormone & Yes & No & No \\
Serum & Yes & & \\
\hline
\end{tabular}

also to engineered the gene-edited chickens to potentially produce non-allergenic eggs.

GM Animal Bioreactor Products. Enzyme, hormone and serum are some bioreactor products that may be produced in the future, and will be utilized for human esthetics, pharmacy and medication. Depend on the type of research, the products can also be used for human as well as for animal needs. Data required for risk analysis of GM animals bioreactor products include of molecular characterisation and compositional characterisation. A biosafety risk assessment worksheet is shown in Table 5.

The molecular characterisation include of 1) general description of GM animal bioreactor product (description of the host; description of gene sources; description of genetic transformation methods; and characterization of genetic modification); 2) product safety information which includes substantial equivalence; changes in the composition; allergenicity; toxicity and 3) other considerations include of marking genes for antibiotic resistance; potential accumulation of substances that have a significant impact on human health.

\section{CONCLUSION}

Regulation for GM animal is required to anticipate the products that will enter the territory of Indonesia. Institution that conduct laboratory and field trial of $\mathrm{G}$ animal breed stocks required to be developed before the products are available in the market. Labelling for GM animal breeds and animal products is a necessity.

\section{REFERENCES}

Andoko E, Candida A, Zmudczynska E. 2018. A review of Indonesia's agriculture development in recent years 2014-2018 [Internet]. [accessed 22th August 2021]. Available from: https://ap.fftc.org.tw/article/1363.

[BPS] Badan Pusat Statistik. 2019. Economic indicators october 2019 publication number 07330.1916. Jakarta (Indonesia): Badan Pusat Statistik.

Brooks J. 2012. Agricultural policies for poverty reduction [Internet]. [accessed 22th August 2021]. Available from: https://www.oecd.org/development/agricultural -policies-for-poverty-reduction-9789264112902en.htm.

Cotter J, Perls D, 2019. Genetically engineered animals: from lab to factory farm. USA: Friends of the Earth US.

Crist E, Mora C, Engelman R. 2017. The interaction of human population, food production, and biodiversity protection. Sci. 356:260-264. doi: 10.1126/science.aal2011.

D'Odorico P, Carr JA, Laio F, Ridolfi L, Vandoni S. 2014. Feeding humanity through global food trade. Earth's Future. 2:458-469. doi: 10.1002/2014EF000250.

Decree of Four Minister. 1999. Biosafety and agriculture GMO of food biosafety. Government Regulation No.21/2005: Biosafety of Genetically Modified Organism.

Dewbre J. 2010. Food security. Paris (France): OECD Publication and Information Centre.

EFSA Panel on GMO 2013. Guidance on the environmental risk assessment of genetically modified animals EFSA J. 11:3200. doi: 10.2903/j.efsa.2013.3200. 
EFSA Panels on GMO and Animal Health and Welfare. 2012. Guidance on the risk assessment of food and feed from genetically modified animals and animal health and welfare aspects. EFSA J. 10:2501. doi: 10.2903/j.efsa.2012.2501.

Gore M. 2021. Genetically engineered animals as food: A regulatory framework under-prepared. UNSW Law J Student. Series 4.

Indonesia Ministry of Agriculture. 2020. Livestock and animal health statistics 2020. Jakarta (Indonesia): Directorate General of Livestock and Animal Health.

Kuiken T, Kuzma J. 2021. Genome editing in Latin America: Regional regulatory overview discussion. Inter American Development Bank, Environment Rural Development and Disaster Risk Management Division. Paper No IDB-DP-00877.] [Internet]. [accessed 22th August 2021]. Available from: http://www.iadb.org.

Law No. 21/2004. 2004. Ratification of Cartagena Protocol.

Law No. 5 /1994, United Nation Convention on Biological Diversity (CBD).

Lievens A, Petrillo M, Querci M, Patak A. 2015. Genetically modified animals: Options and issues for traceability and enforcement. Trends Food Sci Technol. 44:159176. doi: 10.1016/j.tifs.2015.05.001.

Ministry of Agriculture Decree No 36/2016. 2016. Biosafety risk assessment for feed.

Ministry of Agriculture Decree No 50/2020. 2020. Supervising and controlling plant varieties of agricultural genetically modified organisms distributing in the territory of the Republic of Indonesia.

[OECD] Organisation for Economic Co-operation and Development. 2012. OECD environmental outlook to 2050. Washington DC (US): OECD Publishing.

Pasquito LN, 2019. The biosafety regulatory approach and governance mechanism of GM crops in the Philippines. Iapa Proceedings Conference. p. 620649. doi: 10.30589/proceedings.2019.290.
Pritchett-Corning KR, Landel CP. 2015. Genetically modified animals. laboratory animal medicine. Chapter 32. USA: American College of Laboratory Animal Medicine. p. 1417-1440.

Regulation of National Agency of Drug and Food Control No. 6/2018, Indonesia. Supervision on Genetically Modified Food Product.

Robinson TP, Thornton PK, Franceschini G, Kruska RL, Chiozza F, Notenbaert A, Cecchi G, Herrero M, Epprecht M, Fritz S, You L, Conchedda G, See L. 2011. Global livestock production systems. Rome (Italy): Food and Agriculture Organization of the United Nations (FAO) and International Livestock Research Institute (ILRI). p. 152.

Taiz L. 2013. Agriculture, plant physiology, and human population growth: past, present, and future. Theor Exp Plant Physiol. 25:167-181.

UK Statutory Instruments No. 1663, 2014. Health and safety the genetically modified organisms (contained sse), Regulations 2014 [Internet]. [accessed 22th August 2021]. Available from: https://www.legislation.gov. uk/uksi/2014/1663.

Veitenheimer EE. 2016. Challenges and opportunities facing the evolving field of Genetically Modified Organisms (GMO). USA: Thomson Reuters/Aspatore

Vieira LR, Freitas NC, Justen F, de Jesus Miranda V, de Oliveira Garcia B, Nepomuceno AL, FugantiPagliarini R, Felipe MSS, Molinari HBC, Velini EDE, de Campos Pinto R, Dagli MLZ, Andrade G, Fernandes PMB, Mertz-Henning LM, Kobayashi AK. 2021. Regulatory framework of genome editing in Brazil and worldwide [Internet]. [accessed 22th August 2021]. Available from: https://www.alice.cnptia.embrapa.br/bitstream/doc/11 32164/1/Regulatory-framework-of-genome-CAP5.pdf

Zadoks JC, Waibel H. 2000. From pesticides to genetically modified plants: history, economics and politics. Wageningen J Life Sci 48:125-149. doi: 10.1016/S1573-5214(00)80010-X. 